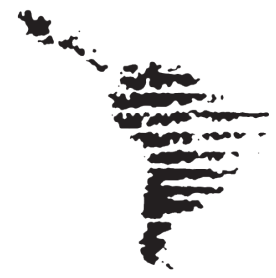

\title{
Human Rights Education in Argentina: Notes on the process of incorporating human rights in educational contexts ${ }^{1}$
}

\section{Educación en derechos humanos en Argentina. Notas sobre el proceso de incorporación de los derechos humanos en los contextos educativos}

\author{
MónICA FERNÁNDEZ ${ }^{2}$
}

\begin{abstract}
This work provides a brief description of the various political and economic contexts that enabled the incorporation of human rights in different Argentine institutions, starting with informal education and eventually coming to form part of the curricula at all educational levels. Its purpose is to visualize how human rights education developed and which spheres of the Argentine culture drove and demanded the need for human rights and human rights education. Since one of the purposes of education is to train citizens, this article intends to show that the practice of human rights is a way of exercising citizenship and that the educational sphere is the proper context for human rights to gain respect in diverse cultural practices.
\end{abstract}

This work seeks to provide an analysis, assessment and critique of the evolution (progress, although in some cases with unusual characteristics) of human rights education in Argentina.

1 This article is a reworking of another that we wrote with Klainer, R. (2008) in: Magendzo, A. (comp.) (2009). Pensamiento e ideas-fuerza de la educación en derechos humanos en Iberoamérica. Santiago: UNESCO, OEI and Ediciones San Martin.

2 Professor and researcher with the Department of Social Sciences; member of the research program Discursos, prácticas e instituciones educativas; Director of the research program Politicas Públicas de Inclusión Social, formación ético-politica de la comunidad UNQ y Educación en Derechos Humanos; Monica Fernandez is a PhD candidate in Philosophy at UNLa and holds a Master's degree in Human Rights from UNLP (thesis entitled "Pedagogical Methods and Educational Practices of Human Rights Education"); an Education Licensure from UNQ; and a Diploma in Social Sciences from UNQ. Former researcher for the program Escuela, Diferencia e Inclusión; Director of the Human Rights Education Academic Network "RedLATEDH" (HUMAN RIGHTS EDUCATION LATIN AMERICAN NETWORK) financed by the University Policy Secretariat of Argentina's Ministry of Education.

Fernandez has been a Cabinet advisor for the Undersecretariat of Human Rights of the Secretariat of Human Rights of Argentina's Ministry of Justice and Human Rights; Director of the CReCER project (Creando Redes Ciudadanas, Educativas y Responsables) and a member of the project Derechos de Todas y Todos. Triple framework: access, knowledge management and acknowledgment - University Extension Secretary's Office (UNQ); member of the PICT project team: Ética del reconocimiento y derechos humanos en la práctica educativa.

Author of La educación en derechos humanos en la Argentina (2013), several specialized articles and several chapters in books. Fernandez has organized (in collaboration) several congresses and roundtable discussions (both national and international) related to human rights and education and has been awarded several national and international scholarships. 
The objective is to identify certain characteristics that have accompanied the short history of the teaching/learning process, both formal and informal, of human rights in the country. Although the main focus is on formal education, this article also touches on certain educational activities undertaken by civil society institutions and NGOs.

In that sense, this work contextually characterizes the political, social, cultural and educational processes that are not ignorant of the tension, debates and silence of education policy in particular and of public policy in general. It could be said that this article seeks to outline the actions and omissions that have been undertaken to address the new ways of understanding citizenship from the period democracy was recovered in the eighties, to present times; or, more precisely, to the midsecond decade of the twenty-first century.

Keywords: Education, Human Rights, Citizenship, Politics

\section{Resumen}

En este trabajo se efectúa una caracterización sintética de los diversos contextos políticos y económicos que fueron habilitando la incorporación de los derechos humanos en diversas instituciones de la República Argentina, pasando por zonas educativas informales y no formales; es decir, comunitarias y jurídicas, hasta llegar a formar parte de las currículas de todos los niveles educativos. El propósito es visualizar cómo se fue desarrollando y desde cuáles esferas de la cultura se fue impulsando y demandando la necesidad de educar en y para los derechos humanos. Dado que uno de los fines de la educación es la necesidad de formar a la ciudadanía, este artículo pretende hacer visible que los derechos humanos son un modo de ejercerla y que la esfera educativa es el contexto propiamente dicho para que los derechos humanos se respeten en las diversas prácticas culturales.

Palabras clave: Educación, Derechos Humanos, Ciudadanía, Política.

\section{Sociopolitical, Cultural and Educa- tional Context}

In 1983 Argentina was just undergoing a process of democratic reconstruction after almost a decade of the worst and most devastating dictatorship of its political history, executor of the bloodiest state terrorism ever practiced. The effects of those years, including the forced disappearance of many young people of a generation that was committed to the ideals of equality, social justice and political participation; the disintegration of the social fabric; and the generation of unprecedented external debt, profoundly marked the years that followed and are still evident today. At the same time, it is a period of rapid change that is shared with many other Latin American countries, not only in terms of politics, but also in the economy, society and culture.

Firstly, a change is produced in the model of the State that had prevailed for almost five decades, transitioning from a welfare state that promoted public enterprises and concerned itself with industrial development and na- 
tional integration, but that was mired with political instability and cycles of democracy and authoritarianism, to a neoliberal state that promotes the market and the private sector and is characterized by a stable political democracy and decentralization policies that place an emphasis on the local/ municipal framework. A triple transition takes place in terms of the relationship between the State and civil society that is characterized by economic liberalization, democratic consolidation and cultural globalization (Garcia, 1996).

Fromapurelyeconomicstandpoint, we can distinguish three distinct periods with very different profiles: an initial period of democratic reconstruction with no social cost (1983-1986) is followed by a period of adjustment "with a human face" (1986-1990) and, finally, by a classical neoliberal adjustment that occurred after 1990. The economic and financial crisis that occurred in 2001 hit Argentina hard, destabilizing the middle-class sectors of society like never before; many became poor and even others homeless. School and community soup kitchens multiplied, destroying what was left of an education system that had been promoting little by little the incorporation of Human Rights Education (HRE) in curricular design.

By 2003 the financial system and, by extension, the economic system were stabilizing, but the remnants of the crisis continued to knock all sectors of society. While the world debated the final evaluation of the so-called Decade for Human Rights Education (19952004), Argentina educated in school cafeterias with very little conceptual content and facing the highest dropout rate in history, growing social violence, increasing discrimination and a job shortage. In May of 2003 a new president assumes political power with the promise to promote and discuss the implementation of public policies in which human rights were strongly represented.

The liberalization period was characterized by a downsizing of the State intended to comply with the rules of efficiency and effectiveness: political openness, privatization, deregulation and decentralization. This included several acts of government, such as transferring education and health services and social programs from the national to the provincial sphere or selling the basic services administered by the State, including electricity, gas, water, telephone, railroads, the national airline and telecommunications, to foreign consortiums at vile prices. In this way, the economic system resembled much more closely the global economy, which clearly meant, or was translated as, a loss of the social and economic rights that had been acquired by a large part of the population.

The introduction of the neoliberal model aggravated social inequality, including a large concentration of income on $15 \%$ of the population, 
the rise of new forms of poverty and a high level of unemployment. The impoverished middle classes suffered from underemployment and so took employment opportunities away from the working classes, giving rise to problem of inclusion and exclusion. The unprecedented rise of pockets of poverty and the growing impoverishment of the once extensive and influential middle class was profoundly shocking for Argentine society. During the 90s, new groups of "workers without work" arose and occupied the public space, taking an active part in the fight to recover lost rights and a minimum standard of living conditions. Picketing became widespread as a way to gain social visibility. Meanwhile, an army of cartoneros $^{3}$ from the very same excluded classes roamed the streets of large cities in human-powered transportation; entire families who found that their only source of income was to collect and sell cardboard and other household waste.

From the point of view of political participation, during the mid-nineties the model of liberal democracy was consolidated, including the party system, pluralism, rule of law, competition and free public opinion. This meant a significant change to the former model of political participation, which transitioned from a "movementist" 4 model to a democracy of opinion, with the media carrying hea-

3 People who work in the collection paper, cardboard and other recyclable materials.

4 Mass political parties tied to grassroots organizations and to the State. vy weight in the conformation of the public space. The loss of confidence of citizens in politics, parties and legislatures was on the rise; skepticism was high and there was a crisis of representation. The idea of control over the government by society as a method of public participation and by the independent media gained ground under the restructuring framework of the Argentinean State.

From a cultural point of view, the limits between public and private were redefined and, as a result, values, social senses and the constitution of identity shifted. The egalitarian culture, which placed an emphasis on the public and collective spheres and on a culture of work, gave way to competitive individualism. The state culture was replaced by a market culture and the State withdrew, leaving many of its responsibilities entrusted to the private sector. Being a citizen became being a customer and a consumer, the reason for which today's struggle is aimed at ensuring inclusion and quality of life. The value of collective interest as a driving force for action was replaced by individual interest. Mobilization against political violence and for the improved security of citizens as well as the fight against corruption and concern for discrimination and the rights of migrant workers were expressed through immediate demands in the social and local spheres. Sight was lost of collective causes based on fundamental human rights, such as employment and adequate housing. 


\section{A New Model of Citizenship: The position of human rights}

From the '80s to today, the concept of citizenship that accompanies political and economic processes has also changed. This new type of citizenship is often called "low intensity" (Auyero and Berti, 1993, p. 120), because the population has fewer aspirations to exercise its social, legal and institutional rights, due in part to unawareness and in part to the education that led to exclusion.

This transformation took place within the framework of a contradictory process of political institutional negotiation, which began with the Trial of the Juntas (1984-85), was followed by the Full Stop Law (1986) and the Law of Due Obedience (1987) and, finally, ended with the Pardon (1989). In 2003, the rise of an ambitious human rights activist to the presidency was a clear sign to reach a consensus on solving the problems of social injustice, as well as those derived from a way of executing justice with respect to several political acts related to State terrorism.

The national reconciliation policy adopted by governments during the ' 80 s and ' 90 s included a limitation on teaching human rights and true democratic mechanisms in schools, despite the consensus reached on their importance. The context prevented teachers from putting into words the memory of the troubled, violent events of the recent past. Moreover, it postponed treatment of relevant yet controversial topics and left sharing any real information with students in the hands of their families. Education on democracy and citizenship was reduced to reproducing scenes from an election, making a reference to different political parties or using the newspaper in the classroom.

At the same time, the 1994 amendment to the Argentine constitution incorporated in its text the most important international treaties on the protection of human rights ${ }^{5}$ as well as new rights and guarantees ${ }^{6}$. These were also included as part of the official curricula for all educational levels. This, however, gave rise to a paradoxical situation in that the more recognition humans rights gained in regulatory frameworks and the more presence they acquired in the media, they seemed to lose meaning in social practice; a process that began after the most recent military dictatorship (1976-1983) but that became more acute with the aforementioned socio-economic transformations that took place during the neoliberal governments.

5 Universal Declaration of Human Rights, American Declaration of the Rights and Duties of Man, American Convention on Human Rights, International Covenant on Civil and Political Rights, Convention on the Prevention and Punishment of the Crime of Genocide, International Convention on the Elimination of All Forms of Racial Discrimination, International Convention on the Elimination of All Forms of Discrimination against Women, Convention against Torture and Other Cruel, Inhuman or Degrading Treatment or Punishment and Convention on the Rights of the Child.

6 Ombudsman, user rights, constitutional protection or amparo, habeas data and habeas corpus, to name a few. 
During this phase, several crucial events took place that reactivated the value of historical memory and justice as a component of social life and the guarantee of State protection of citizens. The terrorist attacks that destroyed the Embassy of Israel in Buenos Aires in 19941992 and the headquarters of the Asociación Mutual Israelita Argentina (AMIA or, in English, Argentine Jewish Mutual Aid Society) in 1994 placed the subject of human rights, respect and tolerance at the forefront of the social debate.

Given the persistence of human rights organizations, the progress made in recent years in the fight against impunity and for the punishment of the crimes committed during the dictatorship reinstated the value of historical struggles and renewed the peoples hope and trust in justice. With the approach of the year 2000, the condemnation of State terrorism and the vindication of the fight for civil and political rights violated by the military dictatorship of the 70 s once again came to the foreground of the public agenda thanks to constant encouragement by the national government.

Several symbolic events have become important dates to help drive work on "recent memory" in schools in particular and in society in general. On these dates, which are represented in the observances calendars promoted by the government, certain events are commemorated in which the fight for human rights by both men and women was evident. Below are just a few examples:

- The significant "Night of the Pencils" on September 16, 1976, when ten students and activists from the Unión de Estudiantes Secundarios (UES or Union of High School Students) were kidnapped, six of whom later disappeared. Today, this date is commemorated as "National Youth Day."

- "Day of Remembrance for Truth and Justice" is a day to commemorate the last coup détat on March 24, 1976, the most violent of all dictatorships in Argentina.

- Another important date included in the observances calendar is April $2^{\text {nd }}$, the date on which "Day of the Veterans and Fallen of the Malvinas War" is commemorated; while June $10^{\text {th }}$ (date of rendition) is commemorated as "Affirmation Day of Argentine Rights over the Malvinas, (other) Islands and the Antarctic Sector."

- One effective method for rescuing historical memory resulted from the process of land recovery of the Escuela de Mecánica de la Armada (ESMA or the Higher School of Mechanics of the Navy), the site where hundreds of people where imprisoned and tortured during the last dictatorship. Today, the building carries the name "Museum of Memory"7 and in 2015 the Museum Malvinas and South Atlantic Islands: Peace, Memory and Sovereignty ${ }^{8}$ was founded on the site.

7 It is interesting to see the variety of activities related to human rights promotion undertaken in this space, including training, guided visits, shows aimed at different age groups, interactive visits, etc. (Memory and Human Rights Space)

8 For more information, visit: Museo Malvinas 
What had been silenced for so long suddenly erupted into the public sphere: the media disseminated the confessions of a former marine, the public self-criticism of the Commander in Chief of the Armed Forces and of the church and directly transmitted the trials of the repressors. While a stable democracy had been established in terms of the political sphere, the model of a neoliberal State produced unprecedented social scenarios and an emptiness of the symbolic meaning of the rights encompassed in the full exercise of citizenship, with a significant loss of access to employment, health and quality education for the working classes. This framework represents an important challenge to human rights education and its significance.

In terms of higher education, in 2004 the first Master of Human Rights program was created at the National University of La Plata'. At the end of two years, two more Human Rights Programs were created: one at the University of Buenos Aires and another at the National University of Cordoba.

In terms of secondary education, also in 2004, the Board of Education of the Province of Buenos Aires decided to permanently incorporate human rights education into the $\mathrm{cu}-$ rriculum. Likewise, several NGOs and other civil associations, such as

e islas del Atlántico Sur: paz, memoria y soberanía.

9 By 2015 several universities had created postgraduate programs in human rights. This will be discussed in more detail further on. the Permanent Assembly for Human Rights (APDH) and the Direct Rights Program, continued their informal learning activities. To top it all, the approval of the new National Education Law (2006), which included several international recommendations on education and human rights, consolidated the rise of HRE in Argentina, despite the fact that, at least initially, it was only by proclamation.

\section{Prevailing Perspectives on Human Rights Education}

The atrocities committed during the most recent military dictatorship in Argentina (1976-1983), extreme acts in violation of human rights, gradually became visible in the political sphere after the restoration of democracy, which was as recently as 1983 . From that time to present day, a series of educational activities resulting from community proposals and government decisions were put into motion. These, of course, showed progress in educational proposals, but also had setbacks as a result of political negotiation. In the paragraphs that follow, we will attempt to show how the human rights debate was gradually introduced into society in general and into the school system in particular.

\section{The Eighties: Introducing the sub- ject into society and schools after the dark period}

In Argentina, democracy and human rights have been a central theme in public debate as of 1983 . For many non-governmental organizations, 
it became necessary to strategize approaches to human rights education to accompany the democratization process. Several international organizations also supported the initiatives, including the Inter-American Institute of Human Rights. In this way, proposals and approaches to education and human rights were generated and their inclusion in discussions at the local, national, and international levels continues even today. One of the main focuses of these initiatives was on transforming schools, particularly in terms of democratization as a revision of authoritarian types of relationships.

These spaces served to analyze the role of human rights in formal education and to prepare proposals aimed at generating the conditions necessary for the validity and promotion of human rights in schools. International legal instruments provided the framework for rethinking the daily problems of school life.

Another main focus was on the inclusion of the human rights debate in schools today. This discussion revolves around whether human rights should be part of the educational content and what that content would look like. Also, whether human rights should constitute a new subject altogether or should be included in all existing subjects. The answers vary greatly, but the majority seemed to agree that human rights education should not constitute a completely new subject in the early, primary and secondary levels of education. This focus went hand in hand with another: the need to raise the awareness of teaching staff of this issue. The different proposals were developed by government and non-governmental organizations alike and the pursuit of bilateral agreements led to:

- The creation of a legal framework, including national laws (in Argentina Law No. 23.849 dated 9/27/1990 ratified the Convention on the Rights of the Child), provincial executive decrees and provincial and municipal curricular guidelines.

- The creation and support of awareness campaigns on human rights and, especially, on the rights of the child.

- The formulation of permanent training or education strategies for educators in human rights.

Redefining and transforming the content on citizenship and human rights was one of the primary focuses of the first years after 1984 (Braslavsky, 1995). As with all of our society's institutions, education was subject to the reassessments and demands of democratization. An important milestone in this process was the Congress on Pedagogy held in 1986, which convened all areas related to education. Parallel to the process of reestablishing the foundations for the 
restoration of democracy, the demand from different social spheres to acquire a greater knowledge on human rights began to gain ground. In particular, the demand was for the inclusion of the subject in educational institutions, an action supported by the debates held at the Congress of Pedagogy.

Under different regulatory formats (laws, decrees, curricular guidelines, etc.) and, in various cases, throughout many jurisdictions of the country, there was pressure to incorporate human rights in formal education. To do this, an appeal was made to those who held extensive knowledge and experience on the subject: the nongovernmental organizations that had fought for human rights during the dictatorship. These organizations, which arose after 1975 for the purpose of denouncing and fighting the flagrant violations committed by State terrorism at the hands of the military dictatorship (1976-1983) and that, at the time, worked on training their own members and activists, were now required to make a contribution to the education of other institutions, including schools. Meanwhile, secretariats of human rights were created in trade and teacher unions around the country, one of whose functions was to train their members.

Organizations such as the Permanent Assembly for Human Rights (APDH), the Ecumenical Movement for Human Rights (MEDH), Amnesty International, the Center for Legal and
Social Studies (CELS) and the Service for Peace and Justice (SERPAJ), to name just a few of the most influential, created outlines and material aimed at the national education system. These organizations began to work informally to train teachers through workshops and seminars and developed publications to be used as teacher support material based methodologically on the tradition of popular education. The content proposals varied greatly, from positions that were more centered on learning the doctrine and recent violations committed in our country, to a perspective of other areas of content from a human rights point of view, to a focus primarily on aspects of social coexistence. During this stage, all efforts to influence the education system were financed externally, particularly by organizations in Northern and European countries. As a general rule, the educational institutions and jurisdictions that benefited from these actions did not contribute financially to their sustainability.

All of these programs sought to raise awareness among teachers of the everyday practice of human rights, as well as to help them understand the fundamental aspects of the human rights doctrine and offer curricular alternatives for incorporating the subject. They also gave priority to the fight against authoritarianism and the intolerance embedded in institutions during the years of the military process. The fact that the proposals originated in these organizations 
reinforced the central position on spreading awareness of human rights, denouncing violations and the need to repair the recent past.

Within the framework of this human rights incorporation process in Argentine society, upon completion of the work of the National Commission on Disappeared Persons (CONADEP), in 1984 the State created an official organization: the Undersecretariat for Human and Social Rights as part of the Ministry of the Interior. Its mission was to promote the joint construction of guarantees for the full exercise of human rights, performing tasks aimed at creating republican awareness of coexistence based on respect for fundamental rights.

Under the leadership of Dr. Eduardo Rabossi during this first phase of its existence, in 1988 the Undersecretariat performed the first official study on the presence of human rights education in the Argentine school system. The study systematically investigated all national and provincial boards of education in order to identify the existing regulations at the primary, secondary and post-secondary levels of education, their degree of implementation and the training status of teaching staff on the subject. It also aimed to evaluate the ways of teaching human rights in the formal education system and to investigate human rights education at national and private universities, particularly within the Schools of Law.
The study's final report (Rabossi, 1988) was intended to communicate the results to international organizations with jurisdiction on the matter and was to serve as the foundation for the organization of conferences on human rights education. The following conclusions were reached based on the information sent by the different jurisdictions:

- Human rights held its proper place in the curriculum of many provinces of the city of Buenos Aires and of the Ministry of Education, as well as in the curriculum of the schools of Law and Humanities. This was classified as progress given the total ignorance of the subject before 1983. The appearance of human rights in education is associated with the ratification of constitutional guarantees.

- It seemed to be accepted at the primary, secondary and university levels that human rights education would be addressed thematically in different subjects. At the university level, however, specific courses were also developed within the legal studies framework. In the case of primary schools, the tendency was to include the subject in Social Sciences in the last two or three years and, at the secondary level, it was included in general education Civics classes. 
- There were significant variations between the provinces as to the importance given to the topic, ranging from explicit non-recognition to full recognition in all its glory. It is worth mentioning that at least eight provinces had resolutions, decrees or laws in force that incorporated human rights education in the education system, albeit under different curricular formats (such as the creation of subjects, inclusion in existing subjects or as fundamentals of curricular design, implementation of special projects and incorporation in the school calendar).

- The absence of teacher training, however, was quite obvious. Training initiatives were undertaken locally particularly in the provinces that were most committed to the implementation of human rights education projects. These initiatives consisted of courses and conferences and, in some cases, were supplemented with teaching support material (Mendoza and La Rioja). The most comprehensive project of this stage was developed by the province of Entre Rios in concordance with the Inter-American Institute of Human Rights. The project was executed over an extended period of time (four year duration) and addressed all areas of teaching, including teacher training.
Additionally, the final report poses what it considers to be the three questions that characterize this stage of "emergence" of human rights in the Argentine education system:

- "Who will be teaching human rights?" What is the desired teacher profile? The report specifies that the desired profile should not only include an extensive knowledge of both facts and regulations, but also of relevant pedagogical techniques and a strong motivation.

- "How should human rights be taught?" What strategies should be followed and how should the subject be included in the curriculum? As to the former, the report mentions the unsettled debate on the need to transmit the information neutrally or for the teacher to be committed to the ideology. As to the latter, it mentions the creation of specific material by specialized teachers or the recognition of human rights content in different courses. While the tendency is to include the subject in different, existing coursework, the report questions whether this is the most appropriate method for the initial phase of the inclusion of human rights education.

- "What will be taught in terms of human rights?" Given the enormous extension of the topic, 
attempts to select or synthesize topics are difficult; therefore, it is necessary to make a decision. On this point, the report refers to the recommendations of the International Congress on the Teaching of Human Rights (Vienna, 1974), insofar as learning should be supported by an interdisciplinary investigation, which leads to a better understanding of the factors that determine a violation of the rights and the determination of policies and institutional mechanisms necessary to guarantee those rights.

These questions were fundamental to all programs developed during this period and it could be said that some are still unanswered today. The work performed at university-level institutions is worth mentioning, however, as the context in which teachers and knowledge are produced. In the university sphere, the most important milestone of this period was the development of specific courses on human rights that were listed as requirements in the curriculums of the Schools of Law of the University of Buenos Aires (1986) and Lomas de Zamora (1984). Other important advances were the incorporation of a Human Rights Lab in the Department of Sociology of the National University of Cuyo, whose objective was to advise the faculty and institutions in general; the inclusion in 1985 of the topic "Constitution and International Treaties" in all courses at the National University of La Plata; and the inclusion of "National Constitution and Human Rights Studies" in the National University of Lujan.

The biggest achievement of human rights promotion and education undertaken by these organizations, which was later channeled into several of the official spaces that were opened, was introducing the subject into society. It gained a cultural space and became a topic of discussion in civil society and would later grow and assert itself in institutions in the decade that followed. An example of this progress is the presence of human rights stands at book fairs, perhaps one of the most important cultural events in Argentina for the past 25 years.

\section{The Nineties: Progress in Public Policies}

In the early ' 90 s, the role of human rights in education was on the decline and was replaced by other topics that seemed more modern and mobilizing, such as environmental protection, AIDS and sex ed., among others. The general consensus was that the lesson in democracy had been learned for good; meanwhile, the market was accepted as the regulating mechanism of human relationships and the discredit of politics and the decline of participation was on the rise (Finocchio, 1999).

The nineties were characterized by the State playing a bigger role in the dissemination and promotion of human 
rights in comparison to the almost exclusive role of NGOs in the previous period. This was possibly due to the fact that these NGOs, which had based their actions in this field on the fight against the State (ruled by a dictatorship), had to adapt during the democratic phase to working alongside the State and incumbent governments, which, in many cases, led to crises, setbacks or difficulty adjusting to the logic of public policy formulation. Several NGOs resisted participating in projects with state organizations, displaying an attitude of suspicion and mistrust, while others accepted the challenge; but what is certain is that the role of several traditional NGOs began to weaken.

The main focus of this period, in addition to the diversification of traditional content on human rights, was represented by the surge of specialized government agencies and the formalization of public policies in relation to human rights education. In many cases, the articulation of actions between the State and civil society made possible the development of concrete action plans with defined objectives, regardless of the differences of opinion that existed between the two sectors. It goes without saying that the process was by no means linear and was rather plagued by contradictions, facing obstacles within the structure of the State itself in terms of the persistence of rationalities, behaviors or attitudes that were incompatible with the defense and ratification and human rights. In many cases, this hindered the complete transformations proposed by those who sponsored the programs, and, as a result, only partial aspects were modified. The most important milestones of this process are the following:

- The constitutional Reform of 1994 made human rights more visible and hindered any process that attempted to backpedal on this matter. Both the consensus reached and the methods of semi-direct democracy incorporated into the text could result in greater citizen participation in political matters in the country. The inclusion of the protection of consumer rights and the right to a healthy environment expanded the protection of citizens and, as a result, their ability to take action. As a consequence of these additions, in all aspects of formal education where the National Constitution is studied, programs will need to be redesigned from an international point of view and with a focus on human rights promotion.

- The inclusion of human rights as a basic component at all levels of education. Human rights are considered to be not only part of the country's positive laws, but also an axiological agreement and a normative fact, as values that encompass various areas of human activity. In this sense and by proclamation, human rights 
were incorporated into the formal education curriculum at the national level and at all levels of education. This action extends to curriculum design for teacher training and to the curriculums of national security institutions and the Armed Forces, as well to the curriculum of all police training courses in the country.

These two actions represent important institutional changes that drove other public policy actions, including the promotion and coordination of the activities of the Undersecretariat of Human Rights ${ }^{10}$. The Undersecretariat became a point of reference and a promoter and centralizer for both official and non-governmental organizations in terms of problems, policies and actions regarding human rights in the country and articulation to foreign nations. Specifically regarding education, from 1991-1992 the main focus of this office was to promote a change of mentality in public officers while strengthening academic activity related to human rights. Through the Undersecretariat of Human Rights, courses, seminars and cultural activities are designed, organized and enacted. The creation in 1994 of the Institute for the Promotion of Human Rights within the framework of the agreement with the United Nations Center for $\mathrm{Hu}$ -

10 At a later date, this Office was renamed the Undersecretariat of Human Rights Promotion, which works under the Secretariat of Human Rights, a dependency of the Ministry of Justice and Human Rights. man Rights for the development of training activities allowed the implementation of the Human Rights Enrichment Program. These training activities were primarily aimed at officers of the state system, particularly security forces (Police and Penitentiary systems) and justice administrators, as well as provincial civil agents. The constitution in 1992 of the Federal Human Rights Council with representatives from each of the provinces and the city of Buenos Aires was intended to guarantee, extend and increase the actions undertaken throughout the country.

In the academic sphere, university courses were developed in other departments, universities and university research centers across the country and an inter-university network was created for the purpose of exchanging information and teaching methods on human rights topics as well as to generate mutual support in academic research and activities.

While this curricular inclusion represented a significant improvement in terms of the generalization of human rights education, important voids sti11 existed that complicated its implementation, and still do today. One of these voids is the absence of a training system for the educators responsible for teaching the content; another is the absence or lack of distribution of adequate teaching materials. Even today with widespread efforts to globalize the dissemination of human rights in 
teacher training facilities, in the majority of cases, the training offered is sustained by non-official channels, i.e., by human rights NGOs.

The same applies to teaching materials at the early and primary levels. While some of the textbooks produced by schoolbook publishers included treatment of human rights topics, each one made its own selection in terms of ethics and civic education, in many cases related to human rights. In the case of grades ten through twelve, called Polimodal in Argentina, there has been a greater and better production of textbooks specific to ethics and civic education. The orientation of these materials and their notion of rights vary greatly: some sustain that the observance of rights is subject to that of duties and offer little else, while others abound in information; still others attempt to teach human rights through a perception of and empathy with situations of infringement (State terrorism, for example); and others present a comprehensive conception of human rights and civic education through the use of good information and an appeal to the real problems faced by adolescents today. In this sense, as of the year 2000, progress was made on proposals that allow adolescents to design their own approach to civic education by strengthening their distinct identities.

Having said that, the biggest weaknesses that accompanied these advances was the absence of systematic, compulsory training programs for the teachers responsible for carrying these new programs forward and the absence of comprehensive training on human rights topics. In addition, we can also add the lack of policy continuity in educational jurisdictions which would allow for the consolidation of the agreements reached.

\section{0 and Beyond: Education} for Effective Citizen Participation

The new century brought with it changes, primarily with respect to political participation and the development of regulations. In education-related areas, progress was made in terms of participation, such as in the debates that led to the enactment of the National Law on Sexual Health and Responsible Procreation (No. 25.673), which created a sexual and reproductive health program for the purpose of equity, equality and social justice and to contribute equal opportunities in terms of sexual health. The debates on this law began years before its ratification in 2003 and in 2006 it was succeeded by the National Program of Integral Sexual Education (No. 26.150).

Furthermore, this law set in motion another important discussion in the education sphere: its inclusion at all levels of the education system. This activated a series of new debates and citizen participation that revealed a new way of doing politics, seen to be more in line with international recommendations. 
Other important laws that have come to form basic legal frameworks are the Law for the Integral Protection of Children and Adolescents (No. 26.061) and the Law on Domestic Violence (No. 24.417), both of which served as a basis for the debate that culminated in the development of educational standards. These two laws are complemented with other legislative milestones, including the Law for the Integral Protection of Women ${ }^{11}$ (No. 26.485) passed in $2009^{12}$ and the recently created Registry, Systematization and Tracking Unit for Femicides and Homicides Aggravated by Gender ${ }^{13}$. We should also mention the recently enacted Law to Promote Coexistence and Address Social Conflicts in Educational

11 In the case of Buenos Aires Province, a program was created to control and offer advice on the scourge of violence against women. For more information, visit the Secretariat of $\mathrm{Hu}$ man Rights of Buenos Aires Province (Secretaría de Derechos Humanos de la Provincia de Buenos Aires, 2015) or the Argentine Ministry of Justice and Human Rights (Ministerio de Justicia y Derechos Humanos, 2015).

12 The law intends to prevent, punish and end violence against women in the areas where they develop interpersonal relationships. The law gave rise to several actions, including the recent Ni una menos conference. The law is available on the website of the Argentine Center of Documentation and Legislative Information (InfoLEG, 2015).

13 For more information on this statistical register, visit the website of the Secretariat of Human Rights of the Ministry of Justice and Human Rights of the Office of the President of Argentina (Ministerio de Justicia y Derechos Humanos, 2015).
Institutions (No. 26.892) ${ }^{14}$ or the Law against Bullying ${ }^{15}$.

The celebration of the World Education Forum and a widespread debate that included the participation of different players in the school community, NGOs and civil society put into motion a new participatory approach that culminated in the approval of the National Education Law (No. 26.206) in 2006.

During this period, actions were consolidated that included the joint participation of State organizations and different, representative organizations of society that worked for the efficiency of human rights. An example would be the World Education Forum held on May 4-6, 2006, in Buenos Aires. The forum was entitled "Public Education, Inclusion and Human Rights" and was organized by Abuelas de Pla$z a$ de Mayo (Grandmothers of the Plaza de Mayo), the Confederation of Education Workers of the Argentine Republic, the Secretariat of Education of the City of Buenos Aires, the Public Policy Lab and the National Movement of Recuperated Businesses. The purpose of the initiative was to place education at the center of the social and political agendas and to open a pluralistic debate on the direction public policies should take so that another education and another

14 For more information on the enactment of the Law of Coexistence in Schools visit the website of the Secretariat of Public Communication of the Office of the President of Argentina. Press Room (Presidencia de la Nación Argentina, 2015).

15 See this note on the Pagina21 website (Pagina12, 2015). 
society would be possible, socializing historical, regional, national and local experiences for such purpose ${ }^{16}$. Following the completion of the forum, the debate for the new Education Law began throughout institutions and at all levels of education.

Following these debates, the ratification of the new National Education Law meant a series of modifications to the Argentine Education System, which were in complete harmony with the recommendations of the World Program for Human Rights Education (PROMEDH) and other international gatherings. It should be noted, however, that the approval of the law still did not imply transfer into curricular design ${ }^{17}$.

Among the key ideas of the new National Education Law (No. 26.206) is the need to guarantee education for life through strengthening integral training and creating a means to offer equal opportunities, while respecting differences and prohibiting gender discrimination of any kind. One of the changes proposed is to encourage students to define their life plan based on the values of freedom, peace, solidarity, equality, respect for diversity, justice, responsibility and the common good. This makes defining an approach to civic education necessary that is committed to the values

16 Source: Education Portal of the Argentine State (Ministry of Education, 2015).

17 For more information on the history of HRE, its content and teaching methods see: Fernandez (2013). of ethical and democratic participation, freedom, solidarity, peaceful resolution of conflicts, respect for human rights, responsibility, integrity, appreciation and the preservation of natural and cultural heritage.

Another regulation that demonstrates how the ideology of human rights is present in the new Education Law is the guarantee of instructional strategies based on intercultural/bilingual perspectives, which guarantees the constitutional right of the indigenous people to receive education that contributes to preserving and strengthening their cultural norms, language, world view and ethnic identity.

Furthermore, and as has been repeatedly recommended by congresses, conferences and international organizations, the articles of the new Law propose involving the media in educational topics, urging them to assume a higher degree of ethical and social responsibility for the content and values they transmit.

With respect to school curricula, a significant change took place in middle-level education. Since education policy was mindful of the civic shortfalls of the years of dictatorship, in 2004 the province of Buenos Aires (the jurisdiction in which almost half of the country's school enrollment is concentrated) decided to incorporate "Human Rights and Citizenship" as a new subject during the second year of the polimodal level, or the third year 
of high school, which was intended to address the primary purpose of polimodal education of developing the aptitudes necessary for the practice of conscious and responsible citizenship. This curricular content was modified by the National Education Law of 2006, and so today new material and programs related to human rights education exist in the province of Buenos Aires and in other educational jurisdictions. Among the changes we should also mention the $\mathrm{Cu}$ rriculum Design for Civic Education in School in the Province of Buenos Aires (2008), which encompasses the first three years of high school. This curriculum, which is valid until the year 2015, includes nine core topics that address human rights in terms of content, methodology and overall framework, which involves discussing aspects of daily life and emphasizing that children and adolescents are also subjects of rights, letting go of the assumption that they a protected group. Also in Buenos Aires, two new subjects were incorporated into the curriculum for the upper cycle of high school, which are worth mentioning for their connection to HRE: Work and Citizenship ${ }^{18}$ and Politics and Citizenship ${ }^{19}$

While human rights education has grown in recent years at the primary and secondary levels, the same can-

18 The general framework is similar to the one described previously. It includes material aimed at students in their 6th year of high school.

19 In this case, the material is aimed at students in their fifth year of high school. not be said for post-secondary education. While it is true that many Argentine universities offer courses on human rights, they are generally elective and teach primarily theoretical aspects more so than the practice of human rights as a means to create and recreate culture. This complicates the transfer of knowledge and, above all, their effective practice. This problem is even more serious at the non-university tertiary level insofar as the lack of inclusion of human rights content in the curriculum has led to their absence even as theoretical content. We have a similar case at universities where these courses are required only for degrees in law and political science.

In order fill some of the absences left by the national education policy at the post-secondary level, a highly important systematic action is currently being undertaken in the university sphere. At the National University of Quilmes (Fernandez, Gongora, Manchini and Ripa, 2008-2013) ${ }^{20}$, various extracurricular activities are being developed, including the Teacher Workshop on Service and Training held since 2008, the purpose of which is to transfer part of the results of the HRE research projects performed by the team since late- 2003 to different educational levels, for which a teacher training program has been

20 The project is financed by the University Policies Secretariat of the Ministry of Education, Science and Culture and the University Extension Secretary's Office of UNQ, and is backed by the Inter-American Institute of Human Rights (2008-2013). 
implemented in three key areas of HRE: integral protection of children and adolescents, civic education and environmental protection.

The proposed teaching methodology focuses on the construction of participatory practices and, as such, is aimed at both active teaching professionals and teachers in training alike, as well as pupils at both the primary and middle levels and any other person of the educational community for the purpose of providing strategies that collaborate with the creation of culture for democracy and human rights. It is commonly believed that human rights education should be approached from a context of transmission and experience and should be incorporated into all levels of the school system. It can be argued that human rights education is about incorporating new habits which, in this case, would be habits of participation.

One of the goals proposed by the project is to modify the role of authority in the classroom, reflecting on solidary teaching initiatives (thus participatory) that represent a responsible, committed teacher who guides students to meaningful learning of scientific and social content while participating and engaging others in the activity. Participating is "partaking of the sociocultural activity," being part of it. Practical/participatory learning meets the deliberative ideals that are intrinsic to democratic life.
In summary, the project was developed taking into account recommendations on the importance of an interdisciplinary, inter-institutional approach. For this reason, not only was scientific knowledge (environmental, communications, legal, educational, methodological, etc.) put into play, but axiological components were also contributed, such as respect for otherness, solidarity, responsibility, democracy, participation and equality.

On the other hand, in mid-May of 2006, the First Inter-American Colloquium on Human Rights Education was held, entitled "Experiences, Problems and Challenges." From that time on, these events have been celebrated periodically at different universities, such as Quilmes, La Plata and Lanus, and in several neighboring countries, including Chile and Brazil, and have extended the possibility of participation to many different people, among which are students, teachers and authorities at all educational levels, including government officials ${ }^{21}$.

21 For more information on the HRE colloquiums and the joint task networks that started developing after these meetings see: Monica Fernandez, "Red de Intercambio de Experiencias Educativas para Promover la Educación en Derechos Humanos (RIEEPEDH): Una experiencia conjunta de trabajo mutuo, integración y compromiso." In: Rodino, A; Tosi, G; Fernandez, M and Zenaide, N. (Comp.) Cultura y Educación en Derechos Humanos en América Latina. Pessoa, J. (Ed.). UFPB, 2014.

Within the framework of the academic agreements that originated in regional meetings, a website is available that summarizes each of the proposals that arose from the HRE colloquiums, which is updated periodically. For more information see: Latin American Network for 
In addition to the first postgraduate degree in human rights created in Argentina, the aforementioned Master of Human Rights offered by the Institute of Human Rights of the National University of La Plata, the same university's School of Journalism and Social Communication offers a Masters in Communication and Human Rights. It is important to mention that while there are also private universities that offer postgraduate degrees in human rights, this article will only mention State-financed institutions, although the fact remains that postgraduate degrees, in general terms, have a minimal cost.

In the case of the National University of Lanus, another pioneer academy in incorporating human rights education into undergraduate and postgraduate degrees, has offered a Master of Human Rights degree since the year 2008. In recent years, this university has also developed a Specialization in Human Rights, Immigration and Asylum and a Doctorate in Human Rights. The School of Law of the University of Buenos Aires also offers both a Specialization and a Master's Degree in International $\mathrm{Hu}$ man Rights Law.

In other provinces of Argentina, specifically in Santa Fe, the National University of Rosario recently created a Master of Human Rights, whi-

Human Rights Education (Red Latina de Educación en Derechos Humanos, 2015) le the University of Tres de Febrero has developed a Master of Human Rights, State and Society. Similarly, located in the northeast of Greater Buenos Aires, the National University of San Martin offers a Master of Human Rights and Democratization for Latin America.

Other academic offerings are also available, however these are offered as undergraduate level programs as opposed to postgraduate. For example, the National University of General Sarmiento offers an Associate's Degree in Human Rights and Territorial Intervention Strategies, while, paradoxically, the National University of Quilmes, with its long history in human rights-related topics, has yet to create a postgraduate degree. As of the late-twentieth century, however, they have developed extracurricular teacher training workshops aimed at teachers and other teaching professionals in service and training, and also offer three elective courses in the undergraduate curriculum.

Other postgraduate human rights degrees that have been created and are run with state financing are the Associate's Degree, Specialization and Master's Degree in Human Rights from the School of the State Attorneys Corps of Argentina's Treasury Procurer and the National University of Tres de Febrero. Also worth mentioning is the Specialization in Human Rights and Education for education professionals offered through 
the Ministry of Education's National Teacher Training Program.

Finally, it must be said that during the last decade, the academic offerings at the undergraduate, graduate and postgraduate levels related to teaching and human rights education have increased exponentially. In addition to these State-financed curricular and extracurricular pedagogical dimensions, there are a number of public social inclusion policies that have been enacted for educational purposes, including the Programa Conectar Igualdad (Connect Equality Program, which offers netbooks and training for teaching staff), FinES (high school completion program), PROGRESAR (subsidies for training and formation) and the Asignación Universal por Hijo (Universal Child Allowance), among other scholarships to university or for primary and secondary education. The ways in which human rights are present in education policy are many. However, the same old problem persists of the presence of human rights in everyday practice, whether in education or in other spheres of society. In closing, it would suffice to paraphrase a great human rights activist, our beloved Uruguayan brother Luis Perez Aguirre, who said that "the magic of human rights education lies in the method."

\section{Conclusions}

The purpose of this article was to provide an overview of Human Rights Education in Argentina. As we have seen, while the academic offering of courses and seminars related to human rights in general and to HRE in particular has grown significantly, there is still a series of absences, among which we find the need to seriously contemplate the concept of HRE, the need to define who is qualified to approach teaching and learning strategies, the minimum human rights content that coursework should include and, above all, the most appropriate method to teach and learn human rights.

With regards to the last point, strategies are urgently needed to help tie HRE to the ethical and political education of citizens. Therefore, the challenge of HRE is the need to educate in awareness, in the urgency to recognize that the other is the same as the self. Finally, and perhaps the most important of the entire HRE framework is that HRE revolves around the political sphere; not just any politics, but one that emphasizes the need to remove the mask and to say once and for all what Rancière (2012) recognized so masterfully when he pointed out that politics is a concept of struggle between the rich and the poor, between the included and the excluded, with a specific distribution of material and symbolic goods, access to which is denied to one of the parties. Politics is about the distribution of the part of those who do not yet have a part, that is, who have yet to receive their part of the distribution.

This concept of politics is even more correct when reflecting on the context of Latin America, where history 
and geopolitics have excluded a sector of the population from the distribution of their portion of everything. As Rancière writes:

There is politics when there is a part of those who have no part, a part or party of the poor. Politics does not happen just because the poor oppose the rich. It is the other way around: politics (that is, the interruption of the simple effects of domination by the rich) causes the poor to exist as an entity. [Therefore, p] olitics exists when the natural order of domination is interrupted by the institution of a part of those who have no part (Ranciere, 2012, p. 25).

\section{References}

Auyero, J and Berti, M. (1993). La violencia en los márgenes. Una maestra y un sociólogo en el conurbano bonaerense. Madrid: Katz.

Barcena, F. (2014). La educación como acontecimiento ético. Natalidad, narración y hospitalidad. San Martin: Miño y Davila.

Braslavsky, C. C. (1995). Educación para la ciudadanía y los derechos humanos, diez años después. En L.-N. En Tiramonti, G. (Ed.) Las transformaciones de la educación a diez años de democracia. (pg. NDA). Buenos Aires: Tesis-Norma.
Espacio Memoria y Derechos Humanos. (Undated). Retrieved from http://www.espaciomemoria.ar/

Fernandez, M. (2013). La educación en derechos humanos en la Argentina. Bernal: Editorial de la Universidad Nacional de Quilmes.

Fernandez, M., Gongora, R., Manchini, N. and Ripa Alsina, L. (2008-2013). CReCER. Creando Redes Ciudadanas, Educativas y Responsables. Buenos Aires, Argentina: Bernal.

Finocchio, S. (1999). Temas de la agenda curricular de ciencias sociales para el 2000. Una propuesta de desarrollo curricular para la Argentina del próximo siglo. Ponencia presentada al Congreso de Logroño (pg. NDA). Logroño: NDA.

Garcia, D. (1996). Estado y sociedad en una época de cambios. Serie de Documentos 201. Buenos Aires: Flacso.

InfoLEG. (2015, August 27). Información Legislativa del Centro de Documentación e Información. Argentina. Retrieved from http://www.infoleg.gov.ar/infolegInternet/ anexos/150000-54999/152155/ norma.htm

Ministry of Education. (2015, $25 \mathrm{Au}$ gust). educar. Retrieved from http://portal.educ.ar/noticias/ educacion-y-sociedad/se-viene-el-foro-mundial-de-ed.php 
Office of the President of the Argentine Nation. (2015, July 31). Press Room. Retrieved from http://prensa.argentina. $\operatorname{ar} / 2013 / 10 / 04 / 44717$-promulgan-la-ley-de-convivencia-enlas-escuelas.php

Pagina12.(2015,July31).Pagina12.com. ar. Retrieved from http://www. pagina12.com.ar/diario/sociedad/3-228909-2013-09-13.html

Rabossi, E. (1988). La enseñanza de los Derechos Humanos en la República Argentina. Buenos Aires: Undersecretariat of $\mathrm{Hu}-$ man Rights. Ministry of the Interior. Argentine Republic.

Ranciere, J. (2012). El descuerdo. Política y filosofía. Buenos Aires: Nueva Visión.

Latin American Human Rights Education Network. (2015, July 25). REDLATEDH. Retrieved from http://redlatinadeedh.com.ar/

Secretariat of Human Rights of Buenos Aires Province. (2015, August 25). BA Secretary of
Human Rights. Retrieved from http://www.sdh.gba.gov.ar/ areas/avm.php

Website of the Ministry of Justice and Human Rights (2015, August 25). Ministry of Justice and Human Rights. Office of the President of the Argentine Nation. Retrieved from http://www. jus.gob.ar/areas-tematicas/violencia-de-genero.aspx

Website of the Ministry of Justice and Human Rights. (2015, June 22). Secretariat of Human Rights. Retrieved from http:// www.jus.gob.ar/derechoshumanos/comunicacion-y-prensa/ noticias/2015/06/22/la-secretaria-de-derechos-humanos-se-reunio-con-periodistas-con-vision-de-genero.aspx

Website of the Museum Malvinas and South Atlantic Islands: Peace, Memory and Sovereignty. (Undated). Retrieved from http:// www.museomalvinas.gob.ar/

Received: 9/19/2015.• Accepted: 9/15/2016 
